\title{
Mad and Bad Media: Populism and Pathology in the British Tabloids
}

\section{Introduction $^{\mathrm{i}}$}

On 15 May 1800 James Hadfield narrowly missed killing George III. Hadfield’s Godgiven plan to kill the king and save the world by certainty of his own death did not include being defended by the brilliant advocate Thomas Erskine, who pleaded his clients’ religious delusions cancelled his criminal intent. The court accepted that Hadfield's lunacy did not compound but exonerated the deed. According to the law Hadfield would be set free once he had recovered his wits, so within days the government passed The Criminal Lunatics Act of 1800. Under its retrospective powers Hadfield was sent to London’s Bethlem Hospital. The new designation of 'criminal lunatic' created by the Hadfield case captures the coming together of law and psychiatry in adjudicating on those deemed insane or responsible (Smith, 1981).

Two centuries on from the Hadfield case, the wheels of law and psychiatry continue to turn on courtroom judgements of insanity and responsibility. In contemporary British tabloids, where emotions expressed in the court of public opinion are at their rawest, the finer points of law and psychiatry hardly matter when apportioning moral responsibility to mad and bad offenders. This is because, in tabloid terms, the madder the offender the better for headline writers because no matter how mad one may be there is no escaping normative judgement. The problem however is that tabloid discourse on 'mad and bad' is irrational, which is not to say we can dismiss it as meaningless because tabloid editors certainly do not. 
The problem that tabloid editors are unable, perhaps unwilling, to grasp is that mentally disordered offenders cannot be mad and bad. This is not news as the Hadfield case shows. In legal and psychiatric terms, offenders who come before the courts can only be considered by juries to be mad or bad; they are mutually exclusive (Prins, 1995). In Britain, where tabloid logic rides roughshod over this distinction, 'mad and bad' has logical dexterity. Simply put, the idea of mad or bad equates to psychiatric and legal adjudications too complex for tabloid logic; mad and bad is easier to grasp, catchy in rhythm and valuable for popular mediation.

In this article I want to pursue popular mediation of mentally disordered offenders to counter media analysis of mental distress that criticizes stereotypical tabloid discourse, but fails to recognize ideologically charged populism at work. By doing so, I do not present empirical data but draw instead on emblematic tabloid discourse on the 'mad and bad', though future empirical work will be needed to sustain the integrity of the argument that I am promoting here. This is not because I prefer to work with anecdotal evidence but because conceptual work is necessary to move beyond a heuristic dictated by tabloid logic on the 'mad and bad'.

\section{Diagnosing populism: tabloid logic on the 'mad and bad'}

The key to unlocking tabloid logic on the 'mad and bad' is the shifting context of Britain's mental health care in the 1990s. Following on from Margaret Thatcher's priority of controlling public expenditure including on crumbling Victorian-built asylums, John Major’s Conservative government in 1993 brought to an end decades of glacial-like movement toward psychiatric care in the community by shifting the locus of expensive institutional care to less costly community settings (Jones, 1993). 
By the end of the 1990s however, Tony Blair's Labour government was calling the policy of mental health care in the community a failure. The news came as a surprise to psychiatric professionals caught up in popular rhetoric on mental health policy.

A number of violent incidents had caught the imagination of journalists, which conveyed the message that 'mad, bad and dangerous' mental patients living in the community were a threat to the 'general public' (Rose, 2002). However, Leudar and Thomas's (2000) discussion of UK newspaper coverage of homicides perpetrated by schizophrenic's shows that victims were primary carers including relatives. What is unusual about their study is that it is concerned with broadsheet reporting, which is traditionally seen as more serious, less sensational journalism than what is written in the tabloid press. Shifts in marketization and personalisation of news have not left these media outlets untainted/untouched from populist reporting on community care.

From a historical perspective populist reporting on mental health care is quixotic. A point easily missed is that tabloids and broadsheets applauded Enoch Powell's 1961 speech when as Conservative health minister he pronounced mental hospitals out of touch with the communities they served and were 'doomed institutions’ (Jones, 1993). In the 1980s, tabloids appeared bastions of liberalism demanding inquiries into abuse of patients still housed in hospitals (Jones, 1993). In the 1990s however, tabloid invective shifted against advocates of community care ('bastards of liberalism' one might call them) when the myth of madness as dangerousness was revivified as a public threat (Rose, 2002). This mutation in tabloid logic on community care reflects Britain’s changing newspaper market. 
In the 1990s, British newspapers witnessed a populist shift as tabloids dealigned from the two major British political parties (Deacon and Wring, 2002). At the same time, market-leading tabloids including the Sun and Daily Mail mobilised a motley assortment of scary 'Others' including asylum seekers, illegal immigrants, and 'mad and bad' offenders against which they protected 'us' from 'them' (Stanyer, 2006). Thus, the 'mad and bad' folk devil reflects a culture of political populism in the UK newspaper market, not a culture of misinformed tabloid journalism cited by anti-stigma campaigners (e.g. Thornicroft, 2006; British Journal of Psychiatry, 2013). Not only does this misdiagnose the problem of 'mad and bad', anti-stigma campaigners also reckon the remedy is to educate tabloid editors in error of their ways.

A case in point concerns Rebekah Wade (now Brookes) when, in 2003, as editor of the Sun she maligned ex-world champion boxer Frank Bruno as 'Bonkers Bruno’, after he was detained in a psychiatric hospital. Readers and mental health campaigners reacted with anger at the intrusion into Bruno’s privacy. Having misjudged the public mood, Wade/Brookes accepted an invitation to be 'educated' on mental distress by Marjorie Wallace, an ex-journalist herself once accused of stigmatizing schizophrenics as dangerous (see Cross, 2010). We can only speculate on the quality of this education, which presumably did not include education on privacy issues. I make this point because in the same year Wade/Brookes told a House of Commons enquiry into press invasions of privacy that her newspaper paid police officers for information, an illegal act conveniently ignored by politicians faced with the prospect of Sun journalists digging into their private life (Watson and Hickman, 2012). 


\section{Read all about it! Political hypocrisy and tabloid news agendas}

In Britain, political hypocrisy is a chronic condition. Indeed, the recent Leveson Inquiry into the culture, practices and ethics of the press showed that Westminster politicians largely accepted this blemish on our body-politic. The point, however, is that populist news agendas are taken seriously by Britain’s political class. As Murdock (2004) shows in his work on British press coverage of genetically modified (GM) food, political reaction moved against the GM food lobby only when tabloid antipathy became apparent. For instance, a memorable Daily Mirror front page photomontage of Tony Blair as Frankenstein's monster cut across arguments of the biotechnology lobby focusing political attention on appeasing public concerns.

Tabloid agendas in the UK have political impact in ways that broadsheets only rarely match and the current study reflects their influential presence. In saying this, I do not ally myself to arguments made by cultural populists (e.g. Fiske, 1992) that taking tabloids seriously means recognising only their anti-elitist popular appeal. This is misleading because the true political importance of tabloids lies in their populist agendas. Thus, politicians like Tony Blair used tabloids for policy announcements, while at other times tabloid editors took the initiative such as Rebekah Wade/Brookes 'Sarah's Law' campaign, named after a murdered child, which saw the News of the World use 'name and shame' tactics to demand from politicians a law identifying sexual offenders in neighbourhoods (see Silverman and Wilson, 2002).

Dean's (2012) recent expose of how UK politicians adjusted their public policies to suit tabloid editors and agendas underlines how the vociferous 'attack dog' 
qualities of tabloids render them a formidable political force. Dean shows how the righteous indignation of the British right-wing press mobilized against 'liberal' policies including on law and order, drugs, asylum, education, child poverty, and health and social care. Dean ignores mental health policy, though Rose (2002) notes fierce political and press backlash to the 'risky’ policy of closing mental hospitals.

In our contemporary culture of risk and blame, politicians and tabloids are preoccupied with the idea of public protection, risk-assessment, and over-hasty implementation of more and more criminal justice measures to deal with psychiatric 'folk devils' (Prins, 2007). This explains Beresford's (2001) experience listening to forked-tongued politicians publicly reject the association of mental illness with crime while 'at private briefings, they and their spin doctors spun a different tune fuelling demands for a more custodial form of mental health care, as advanced by the Sun and Daily Mail' (Beresford, 2001: 504). UK prisons are filled with human consequences of this hypocrisy; nine out of ten prisoners in British jails have one or more mental illness yet there is little or no community care on their release (NIHR, 2010).

Given the history of journalists advocating on community care noted above, this seems a worthy cause. However, an iconic case in policy perception terms remains the 1992 killing of Jonathan Zito, killed by Christopher Clunis, a violent schizophrenic (Jones, 1993). Zito’s killing occurred within months of the community care policy being introduced and the lasting perception this incident created can be seen in a 2009 Sun headline trumpeting their interpretation of news that Clunis was to be transferred from Rampton maximum security hospital to a medium-secure hospital 
as: ‘ZITO’S CRAZED 18ST KILLER TO GO FREE’ (24 March 2009, p. 15). The perception that care in the community is dangerous was forged in this tragic event.

The language of psychiatric otherness provides shorthand for scary media stories on mentally disordered offenders. A seminal influence has been Philo (1996) whose work on British media and mental distress identified stigmatizing words ('crazed', 'mad', 'nutter', and so on) associated with misrepresentation of mental illness in the media. However, the linguistic domination of anti-stigma campaigns in the British media (Harper, 2005) and other English-speaking countries such as Australia (Holland, 2012) bypasses the question: what is going on discursively? A fixation on stigma misses how mentally disordered offenders can be made to appear morally irresponsible, for instance when they commit murder. This moral tension is embedded in historical and contemporary reporting on insanity and responsibility.

\section{Mad, bad - or sick?}

In 1843 the trial of Daniel McNaghten for the murder of Edward Drummond was controversially stopped on grounds of insanity. The trial was news because the intended victim was Prime Minister Sir Robert Peel and led to new rules clarifying the legal basis for criminal insanity. The verdict was also controversial because McNaghten was put under psychiatric lock and key in Bethlem Hospital. Concern was voiced in the press that if McNaughton 'was allowed to get off scot-free - as perpetual confinement in a lunatic asylum came to be regarded - the streets would soon be seething with madmen rushing hither and thither killing prime ministers in all directions (Allderidge, 1974: 53). In fact, McNaghten’s confinement can hardly be 
described as getting off 'scot-free' since he endured Bethlem's prison block for two decades before being transferred in 1863 to the new Broadmoor Criminal Asylum.

By coincidence, another more recent failed prime ministerial assassination attempt began a chain of mass murder that has given insanity and responsibility contemporary worldwide focus. On 22 July 2011 Anders Behring Breivik exploded a bomb outside the Norwegian prime minister's office that killed eight and injuring scores. A few hours later Breivik arrived at Utoya Island, the site of a Labour party youth camp where he systematically shot and killed 69 people, mainly teenagers. The shock was compounded by Breivik’s reported statement that his actions were 'necessary' to awaken Norway to the threat posed by Islam. Breivik’s appointed lawyer responded by telling journalists that his client was obviously insane.

Four months after the attacks psychiatric thinking caught up with the lawyer's reasoning. Psychiatrists diagnosed Breivik to be a paranoid schizophrenic not responsible for his actions. In an unusual twist, Breivik’s trial hinged on prosecution attempts to declare him insane while his defence argued his actions were politically repulsive, though entirely sane. In the end the Norwegian court declared Breivik's views on multiculturalism, immigration and Islam absurd not delusional, and his claim to be part of a modern-day Knights Templar movement judged nonsense rather than paranoid deluded ramblings. However, I do not want to lose sight of lay reasoning that the massacre was a 'mad' thing to do since underlying this view are two popular misconceptions about mental disorder and crime. Firstly, that outrageous crimes must entail mental illness, and secondly, that the purpose of psychiatry in the courtroom is to 'get people off'. Such reactions are common (Wessely, 2012). 
When psychiatrists diagnosed British serial killer Peter Sutcliffe, popularly known as the Yorkshire Ripper, a paranoid schizophrenic at the time he killed thirteen women between 1975 and 1981, the judge insisted this evidence be put before a jury because he was concerned the public would think that a diminished responsibility verdict would suggest Sutcliffe had escaped punishment (Bilton, 2003). The Attorney General initially accepted the psychiatric diagnosis, but was then required to argue against it. Thus, when Sutcliffe took the stand audible gasps were heard in court when the Attorney dramatically held up Sutcliffe's sharpened screwdriver that he had used to repeatedly stab his victims to death. There could be no doubt that here was a deliberate legal strategy to render Sutcliffe either mad or bad, but certainly not both.

In their commentary on Sutcliffe’s trial, Blackman and Walkerdine (2001: 129) note how the court proceedings highlight 'the way in which distinctions between the mad and the bad converge in the adjudication of the 'criminal personality', They emphasize how psychiatric or psychological knowledge underpins the distinction between madness and badness in adjudications on Sutcliffe's motivation to kill, and hence his responsibility. Thus, Blackman and Walkerdine point out that most of the press reporting on the trial focused on Sutcliffe's apparent faking and simulation of voice hearing, but misses adding that signs of Sutcliffe’s culpability were meaningful only through perceived absence of any recognisable sign of madness.

\section{Deceptive appearances and culpable conditions}

Asking the deceptively simple question, 'what is madness?', the psychoanalyst Darian Leader (2012) argues that we should revise our understanding of madness in both 
clinical and popular senses. Leader discusses the disturbing case of Harold Shipman, the British doctor who quietly went about murdering at least 250 of his patients, probably many more. In Shipman’s case there was no violent outburst, no socially inappropriate behaviour, or any noisily delusional system that he felt compelled to broadcast. Leader suggests these are significant absences because Shipman was found not have any mental illness, yet by any normal standards his actions were 'mad'.

Britain's tabloids have responded to madness and murder by focusing on the 'medicalization of evil' (Mason, 2006), which hardly explains horrific crime, but since the 1863 opening of Broadmoor Criminal Asylum has given us a popular image of homicidal insanity (Winchester, 1999). This is why Sander Gilman (1988) has noted that when it comes to seeing the reality of mental disordered offenders in the courtroom, we are surprised to see not 'mad-dog' looking criminals of popular representation but ordinary-looking folk whose appearance conflicts with stereotypical perceptions of the aggressive 'mad'. Gilman asks:

What happens when it is not the identifiable 'mad person' who turns out to be aggressive, but the 'normal, nice kid next door?' We have a pattern ... of evident public surprise when the 'mad bomber' turns out to be a retired, meek little man living on a pension, or the 'son of Sam' [US serial killer in the 1970s] turns out to work for the post office and live in a high-rise apartment. Such a context is not appropriate for the ‘mad-dog killer’ (Gilman, 1988: 13).

Gilman's point has especial resonance if we consider hundreds of elderly people who no doubt smiled and thanked Dr Shipman as he administered drugs that murdered 
them. How 'mad-dog' criminals are supposed to look - maniacal, out of control, running amok, and so on - underpins what Gilman says is 'the paradox inherent in understanding the popular notion of the mad as criminal' (Gilman, 1988: 11).

When a mad-dog killer turns out disappointingly ordinary the popular image of homicidal insanity helps manage this paradox. An illuminating case in point concerns the Australian Martin Bryant who in April 1996 massacred 35 people in Tasmania. The mass killing was headline news around the world including in the British tabloid Daily Mirror, where Bryant's courtroom admission of guilt was headlined: 'I’m guilty ... ha ha ha' (12 November 1996, p. 4). The story describes Bryant as a 'psycho who never stopped smiling', the significance of which is shown in family photos of Bryant from baby to adult 'still smiling'. Bryan's smile conveys sinister meaning because the focal image is of adult Bryant looking unmistakably 'mad'. Readers still uncertain as to what the image means relied on the caption: 'The mad staring eyes of Martin Bryant who finally confessed yesterday’.

In their analysis of Australian broadsheet reporting on Bryant, McCarthy and Rapley (2000) discuss how in answering the question, 'why did he do it', eye-witness testimony confirms Bryant's appearance as a 'nut' long before he carried out the massacre. However, their analysis of the 'psychiatric case' made against Bryant using lay terminology such as 'crazy' and 'nut', as well as medico-legal terminology such as 'insane' and 'schizophrenic', does not consider how Bryant's insanity was visually mediated, which is surprising given that the photograph showing Bryant's 'mad staring eyes' was later found to have been 'manipulated to lighten the eye area [and] 
left Bryant looking quite deranged’ (Turner, 1996: 269). The source of the manipulation proved to be Rupert Murdoch’s flagship newspaper The Australian.

The Bryant case remains instructive not only for how the actions of a mass killer are attributed to insanity and otherness but also because press reports that initially 'diagnosed' the killer a 'nut' soon after emphasized his moral accountability. McCarthy and Rapley show Bryant's identity was reconfigured as psychologically disturbed but not entirely insane since this would remove his criminal culpability. Linguistic analysis of Bryant as initially a 'psychiatric case' and later a 'criminal case' is insightful for how press reporting renders the killer 'both of us and not us' (McCarthy and Rapley, 2000: 166). McCarthy and Rapley’s linguistic analysis stops at the point where this ambiguity gets socially interesting not least if we consider what might our reaction be to a killer with the soubriquet 'mad' appearing like one of 'us'.

For instance, in 1997 the reappearance of Peter Sutcliffe from Broadmoor was imagined by Chris Morris whose British TV show Brass Eye included a spoof news report that Sutcliffe was on day-release from Broadmoor to rehearse a West End show, 'Sutcliffe: The Musical', based on his life. A Sutcliffe look-alike is shown singing 'I'm so very, very sorry” while his fellow 'performers' tell how he jumps out like a pantomime villain shouting 'boo'. UK tabloids condemned Morris’s 'humour' (see Mulholland, 1997) missing the point that he was satirising media promotions of violent ex-gangsters like 'mad' Frankie Fraser, who had spent some years as a patient in Broadmoor Hospital, but whose 'lovable-old-rogue' celebrity image at that time was such that he fronted all manner of entertainments including a tabloid column in which he admitted enjoying being a torturer and murderer (Mulholland, 1997). 
The absurdity of Peter Sutcliffe on day-release from Broadmoor obfuscates British tabloid's past and current hypocrisy on sexual violence against women. For instance, press reporting during Sutcliffe's 1981 trial voiced sentiments equivalent to Sutcliffe's view that women walking out alone at night were not 'innocent' (Hollway, 1981). Smith (1990) also observes how Sutcliffe boasted of 'prostitute bashing' without fear of criticism, which widens the lens of culpability. Indeed, Smith notes how police hunting for the Yorkshire Ripper spoke of hating prostitutes while at the same time were using their services. However, more than thirty years on from these events we still find UK tabloids like Murdoch's Sun peddling semi-naked images of young women while boasting they are a 'family' paper. Such are continuities of hypocrisy that British tabloid and police ‘watchdogs' failed women then and now.

Smith (1990) also reveals how Sutcliffe remained undetected because incompetent policing missed clues to his appearance including photo-fit pictures from surviving victims that bear remarkable resemblance to Sutcliffe’s mug shot taken when he was arrested in 1969 for going equipped to steal (though it now seems certain he was attacking women). When police disastrously narrowed their hunt to only consider suspects with a north-east English accent following a hoax tape, surviving victims were ignored when they insisted their attacker spoke in a local Yorkshire accent. Smith notes that the detective leading the hunt for the Yorkshire Ripper told reporters he would know the killer when he saw him. Such fictional detection is hard to reconcile with the reality that Sutcliffe was interviewed by police on nine occasions during which time he continued to kill; appearances can be tragically deceptive. 


\section{Broadmoor patients and tabloid offenders}

It transpires that Peter Sutcliffe was not the only Yorkshire man able to hide in plain sight while serially offending. In Britain, recent revelations about the broadcaster and celebrity Jimmy Savile has revealed that beginning in the 1950s he carried out hundreds of sexual assaults on mainly young children and teenagers over five decades spent as a high profile volunteer in hospitals including Broadmoor. This accounts for a photograph, taken in Broadmoor around 1991, showing Sutcliffe meeting boxer Frank Bruno, while Savile looks on. Until recently the photograph’s main significance was in terms of breached hospital privacy/security giving us a rare sighting of Sutcliffe inside Broadmoor. It has since assumed other sinister meanings in its conflation of Sutcliffe's psychiatric otherness with Savile’s criminal otherness.

The photograph also has other meanings because in a genuinely bizarre turn of events it transpires the photograph was taken when Savile was running Broadmoor, having been appointed to this role in 1988 by Edwina Currie, then Secretary of State for Health. Savile’s 1980s BBC TV children show Jim'll Fix It underpinned his persona as able to 'fix' what politicians could not, i.e. Broadmoor's image. Savile reportedly could access all areas of Broadmoor, a sign of his celebrity power, but also a symptom of what happens when societies' most feared are out of sight, out of mind.

In the 2012 TV documentary that finally revealed him to be a predatory sexual offender, ex-Broadmoor patients and nurses told how they had joked that Savile was a psychopath who ought to be a patient in the hospital, not running it. A variant on the comedy song about lunatics taking over the asylum, it now has an ironic ring of truth about it since paedophilia is also a psychiatric disorder. Taking the humour seriously 
steers us to mediation of popular confusion about the therapeutic work of places like Broadmoor predicated on rehabilitating patients including those who commit crime. In a rare instance of journalistic self-criticism on tabloid reporting on Broadmoor, David Brindle in The Guardian noted how it appeals to our prejudice,

to be told that, in the words of the cliché, that 'the lunatics have taken over the asylum’: that liberalizing the old custodial regime has played into the hands of the patients; that killers and rapists, blessed with animal cunning, are running rings round helpless staff; and that therapeutic care is wasted on psychopaths who are beyond treatment and should be banged up for life (4 May 1997, p.19).

The notion that care is wasted on 'killers and rapists blessed with animal cunning' underlines tabloid logic for symbolic reckoning with mad and bad offenders. But just as we recognize that psychiatric otherness reflects tabloid logic it also gives sustenance to culturally embedded narratives about being crazed and criminal.

The challenge for UK forensic professionals is working in a climate of popular fear about the mad and bad (Prins, 2007). This explains why Broadmoor shows film of its rehabilitation and security regimes on the hospital's web site. This counterpoint to tabloid logic is not unique. In the case of Michael Stone, a psychopathic drug addict who murdered a mother and daughter, and nearly killed another daughter, a public relations firm was employed by his health trust to rebut press inaccuracies about his treatment prior to the murders, but failed to influence press reporting on the case 
(Prins, 2007). This not surprising however because when UK tabloids question the meaning of psychiatric treatment their logic is to be querulous not questioning.

I want to develop this point by considering two cases of Broadmoor patients emerging into the full glare of tabloid publicity. Firstly, the case of violent rapist Lee Porritt was front-page news in The Sun in June 2008 shortly after he was released from Broadmoor into a sheltered hostel. Porritt was secretly filmed in the hostel apparently confirming that he still felt he was a danger to women (readers were also invited to watch a taped interview in the paper's online version). The front-page headline, 'I'm a psycho rapist ... Why did Broadmoor free me?' (The Sun 26 June 2008, p.1) confirms that the paper's wider target was the hospital's efforts to rehabilitate mentally disordered offenders like Porritt back into the community.

The next day’s headline in The Sun entitled 'Lifer Luxury’ (27 June 2008, p.1) was accompanied a photograph showing Porritt literally 'held by cops' apparently on his way back to Broadmoor. The report details Porritt's claim that he and other patients in Broadmoor's Paddock Unit, which specializes in treating psychopaths, were allowed to purchase Yves St Laurent fashion wear stocked by the Broadmoor shop, had nurses buy them sexually violent DVDs, buy flat screen TV's for their rooms, and so on. The paper's editorial, ‘A question of public safety' demanded Government investigation into Porritt's claims about Broadmoor’s regime stating, 'It would mean there has been a serious failure of responsibility in the hospital holding lethal and evil maniacs ... For the sake of public safety, the Government must ask urgent questions today' (The Sun 27 June 2008, p.8 emphasis in the original). 
It is rare that a tabloid with the Sun's reputation for sensationalism reports a legitimate investigation on a dangerous mentally disordered offender in the community. This is so despite the paper's editorial being a model of scandalized rhetoric fused with conciliatory language occupying the moral high ground: 'The Sun accepts that Broadmoor's special circumstances mean some of its procedures will not be the same as a conventional prison' before going on to criticize 'monsters who enjoy luxury' while 'British troops are living in rat-infested barracks'. However, in the wake of the Murdoch press’ phone hacking of relatives of dead British soldiers, rat-like imagery can backfire on tabloid journalism's self-interested claim to employ rat-like cunning when advocating on behalf of ordinary people’s interests.

For instance, the idea that tabloid journalists are simply rat-like was wittily promoted by the acerbic British novelist Will Self during his terse exchange with exNews of the World reporter Paul McMullan on the BBC's Newsnight programme (30 November 2012), when the latter attempted to justify dubious tabloid practices such as bypassing privacy rules. As the Leveson inquiry showed time and again, tabloid editors and reporters displayed breath-taking contempt for privacy laws with McMullan (in)famously stating in classic tabloid-speak, that 'privacy is for paedo's [paedophiles] ... no-one else needs it. Privacy is evil’ (quoted in Sabbagh, 2011).

With McMullan’s perverse line of thinking in mind, overcoming privacy rules is all in a day's work for British tabloids. In their submission to the Leveson Inquiry, the Royal College of Psychiatrists highlighted numerous breaches of privacy rules pertaining to Broadmoor's security and therapeutic work including payment for letters sent to/by patients. Their submission also notes how a Sun reporter falsely applied to 
work as a healthcare assistant in Broadmoor and later claimed to have had access to confidential records. The College also noted that intrusive reporting creates a breach a trust between forensic staff and patients making their work much more difficult.

A particularly worrying case in point involved patients and staff in an English secure unit specializing in treatment of sexual offenders, who were targeted by the now defunct News of the World. The paper produced a series of 'investigative' reports entitled 'Monster in the mall', accompanied by a phone line for readers to report on patients visiting local towns (Sen and Adeleke, 2007). There is a genuine irony (not to say monumental hypocrisy) in the News of the World using leaked or possibly stolen medical records that resulted in a dangerous breakdown of trust between sexual offenders and staff in a clinical context based on relapse prevention.

McMullan's view that 'privacy is evil' is not only perverse; it also sees privacy as a threat to tabloid-wheeling-and-dealing in human distress. For instance, Golding (2005: 111) cites a Daily Mirror headline, 'Bananarama Star in $£ 300$ a Day Mental Clinic'. We can only speculate on how the paper acquired this information, but what is certain is that it had no qualms about using this as a 'show business' story, ignoring the distress of the pop star upon which it feeds. However, ignoring human distress is easy if like ex-Westminster lobby correspondent Chris Moncrieff one does not have the ordinary human problem of struggling with a conscience:

For myself I have never yet been able to locate a conscience even if I had wanted to struggle with it. We are in the business to write stories to sell newspapers. I think we are part of the entertainment industry at the 
downmarket end. We do it for the money. And if that serves the public at the end of the day - well, that's a bonus (cited in Golding 2005: 167).

Normally, absence of conscience is a feature of the psychopathic personality and we must hope that Moncrieff's missing conscience is journalistic hyperbole. However, his point about the business of writing entertaining stories is telling for the murky line separating public interest from prurient interest. Consider Ruth Runciman’s account of visiting Broadmoor in her mental health charity work:

I am increasingly aware of the gap between what I have seen and the picture painted for the public by the tabloid press. For them, the story of Broadmoor is the story of a few notorious killers, told in the most lurid language. Their information is often obtained by an invasion of privacy and trade in breaches of confidentiality, in an area where, by common agreement, adherence to the press's code of practice is particularly relevant in view of the powerlessness and vulnerability of the subjects (Runciman, 1996: 12)

Long before the News of the World phone hacking scandal rendered privacy and prurient interest a matter of public concern, lone voices like Runciman were at work holding tabloids to account. Here, Runciman highlights trade in breaches of privacy that underpin reporting on notorious killers. While she bemoans UK tabloid practices, she also rightly notes there is a legitimate public interest in work being done with Broadmoor patients, some of whom have committed very serious index offences. 
Thus, my second example of a Broadmoor patient emerging into glare of media publicity concerns the high profile case of Robert Napper, convicted in 2008 for the 1994 killing of Rachel Nickel on Wimbledon Common. When Napper confessed to Nickel's murder he was already in Broadmoor having been convicted in 2003 for other sex crimes including rape-murder. The day following his admission of guilt for Nickel's murder, Napper featured in every UK broadsheet and tabloid. The Sun again is especially interesting for its use of a long-lens photograph taken of Napper apparently walking in the grounds of Broadmoor having just fed hens. An adjacent editorial entitled, 'Cosy life of a twisted killer', puts the issue thus:

Hens clucking at his heels, a balding man enjoys a stroll in the fresh air through a vegetable garden. But this is no gardener pottering on his allotment. This is butcher and rapist Robert Napper, a monster whose crimes stand comparison with Jack the Ripper. And the question The Sun asks today is this: Can it be right that a man who has so savagely taken the life of others is allowed to live such a cosy life himself? ... The Sun accepts that Napper is severely mentally ill. But he has done terrible things. Common decency demands that the way our justice system treats him reflects his crimes. Yet he passes his days pleasantly in an institution that seems to have become a cross between a country club and a variety theatre (19 December 2008, p.8, emphasis in the original).

This editorial exemplifies what I suggest is a twofold tabloid interest in reporting on offender-patients. On the one hand, tabloid interest in the offender resides in their human interest and sensationalist news values; but their interest in the patient is an 
expression of more general authoritarian/anti-liberal proclivities. These create logical tensions in their responses - the more insane a person is, the more their actions confound mainstream moral codes, the bigger the story is; the consequence of this is that tabloid thirst for retribution is thwarted when offenders are mentally disordered.

In the tabloids, psychiatric otherness matters in imaging mad and bad offenders, but what also matters to them is accountability i.e. that while the insane are not governed by our mores, our mores will none the less prevail. A convenient solution to this tension is for tabloids to employ their logic of 'crazed culpability' on mentally disordered offenders with the result an ironic twist in moral accountability (Cross, 2010). The idea of crazed culpability suggests the mentally disordered are not like 'us', but when they commit crime there will be a reckoning to us. However, the scandal of Jimmy Savile’s sexual offending including at Broadmoor has illuminated the self-serving differentiation of madness and badness promoted by the tabloids.

Rumours of Savile’s sexual predilections for young girls occasionally surfaced in media profiles from the 1970s, yet Britain's tabloids and TV executives promoted him as a 'secular saint' (Clare, 1992; cf. Furedi, 2013) even after paedophilia gravitated from a psychiatric disorder to a public concern. We can only speculate on why muck-raking tabloids like the News of the World never pursued Savile’s seemingly psychopathic behaviour. What is certain however, is that he was protected by social mores around mental disorder, physical disability, and vulnerable children that emphasised 'us' and 'them' distinctions, which effectively silenced his victims. 
In light of the News of the World phone hacking scandal and likely custodial sentences for guilty editors and reporters, it makes sense to also add that illegal acts on which tabloids have traded for scoops involve fluctuating criminal fortunes, which in prison will make 'us' and 'them' distinctions nonsensical. It might be tempting to dismiss the paradoxical logic of tabloid journalism as equally nonsensical because in the case of mentally disordered offenders, we have ended up with people so 'sick' they must be treated in a different way to 'ordinary' offenders (i.e. through medical diagnosis and treatment), yet so 'evil' they must be punished. We must guard against this impulse lest individuals and minority groups continue to suffer tabloid pathology.

As with deluded individuals in a state of cognitive dissonance, Leveson confirmed that Britain's tabloid newspaper market is incapable of self-diagnosing the ethical chasm into which falls its spurious rhetoric of 'just business' (Wring, 2012). We must none the less aim to bring reason into their pathological world view, restoring them to a time not so long ago when pre-pathological tabloid values added to rather than subtracted from the stock of humanity. This is not the grandiose, even delusional, task it might once have seemed since it is the impetus for Leveson's recommendations that politicians and other interested parties seek a regulatory mechanism for press conduct. Leveson's challenge to reform the relationship between the UK press and politics means that we can no longer tolerate perverted tabloid ethics or else their populist-pathological mores further infect our political discourse.

\section{Conclusion}

I want to conclude by asking the question: post-Leveson does British tabloid logic still matter politically? The answer is it does because tabloids are the main cultural 
arena that daily constructs stories of urban criminality and the mentally disordered are required to take their place in the pantheon of modern folk devils including predatory paedophiles, child killers, and serial killers. British tabloids have too long been left to distort legal, moral, and humanitarian responses to mentally disordered offenders, and if we were to diagnose the consequences of this condition we should declare it insane.

\section{References}

Allderidge, Patricia (1974) 'Criminal insanity: from Bethlem to Broadmoor’ Proceedings of the Royal Society of Medicine 67(9): 897-904.

Bilton, Michael (2003) Wicked Beyond Belief. The Hunt for the Yorkshire Ripper. London: Harper Collins.

Blackman, Lisa and Valerie Walkerdine (2001) Mass Hysteria: Critical psychology and media studies. Basingstoke: Palgrave Macmillan.

Brindle, David (1997) ‘Shock news at Broadmoor’, The Guardian, 24 April: 19. British Journal of Psychiatry (2013) Reducing stigma and discrimination: Evaluation of England's Time to Change programme. Vol. 202(s55). Special edition. Clare, Anthony (1992) In the Psychiatrists Chair, London: Heinemann. Cross, Simon (2010) Mediating Madness: Mental Distress and Cultural Representation, Basingstoke: Palgrave Macmillan.

Deacon, David and Wring, Dominic (2002) 'Partisan de-alignment and the British press’, pp. 197-211 in J. Bartle., I. Crewe, and B. Gosschalk (eds.). Political communications: the British General Election of 2001. London: Frank Cass. Dean, Malcolm (2012) Democracy Under Attack: How the media distort policy and politics, Bristol: The Policy Press. 
Fiske, John (1992) 'Popularity and the politics of information', pp. 45-62 in P. Dahlgren and C. Sparks (eds). Journalism and Popular Culture, London: Sage. Furedi, Frank (2013) Moral Crusades in an Age of Mistrust: The Jimmy Savile Scandal, Basingstoke: Palgrave Macmillan.

Gilman, Sander (1988) Disease and Representation: Images of Illness from Madness to AIDS, Ithaca: Cornell University Press.

Golding, Peter (2005) 'Telling stories: sociology, journalism and the informed citizen’, pp. 165-177 in D. McQuail, P. Golding, and E. De Ben (eds) Communication Theory and Research: An EJC Anthology. London: Sage.

Harper, Stephen (2005) 'Media, Madness and Misrepresentation: Critical Reflections on Anti-Stigma Discourse' in European Journal of Communication, Vol. 20(4), pp. 460-483.

Holland, Katie (2012) 'The unintended consequences of campaigns designed to challenge stigmatising representations of mental illness in the media', in Social Semiotics, Vol. 22(3): 217-236.

Hollway, Wendy (1981) ““I just wanted to kill a woman” Why? The Ripper and Male Sexuality’. Feminist Review 9: 33-41.

Jones, Kathleen (1993) Asylums and After. A Revised History of the Mental Health Services: From the Early 18th Century to the 1990s. London: The Athlone Press. Langer, John (1998) Tabloid Television: Popular Journalism and the 'Other News'. London: Routledge.

Leader, Darian (2012) What is Madness? London: Penguin.

Leudar, Ivan and Thomas, Phil (2000) Voices of Reason, Voices of Insanity, London: Routledge. 
McCarthy, David and Mark Rapley (2001) 'Far from the madding crowd: psychiatric diagnosis as the management of moral accountability', pp. 159-167 in A. McHoul and M. Rapley (eds). How to Analyse Talk in Institutional Settings: A Casebook of Methods. London: Continuum.

Mason, Tom (2006) (ed) Forensic Psychiatry: Influences of Evil, Totowa, New Jersey: Humana Press.

Mulholland, John (1997) ‘Mock Horror’, The Guardian Media Section, 10 March: 3. Murdock, Graham (2004) ‘Popular Representation and Post-Normal Science: The Struggle over Genetically Modified Foods’, pp. 227-259 in S. Braman, (ed) Biotechnology and Communication: The Meta-Technologies of Information. New Jersey: Lawrence Erlbaum Associates.

National Institute for Health Research (2010) The pathway of prisoners with mental health problems through prison health services and the effect of the prison environment on the mental health of prisoners. Available at: http://www.ohrn.nhs.uk Philo, Greg (1996) (ed) Media and Mental Distress, Harlow: Addison, Wesley and Longman.

Prins, Herschel (1995) Offenders, Deviants or Patients?, London: Routledge. Prins, Herschel (2007) ‘The Michael Stone Inquiry. A somewhat different homicide report'. Journal of Forensic Psychiatry and Psychology 18(3): 411-431. Rose, Nikolas (2002) ‘At risk of madness’, pp. 209-237 in T. Baker and J. Simon (eds.) Embracing Risk. Chicago, IL: University of Chicago Press. Royal College of Psychiatrists (2012) 'Supplementary evidence to the Leveson Inquiry’. http://www.levesoninquiry.org.uk/witness/royal-college-of-psychiatrists/ [accessed 30 May 2013] Runciman, Ruth (1996) 'Tell the truth about Broadmoor’, The Times, 17 January: 18 
Sabbagh, Dan (2011) Paul McMullan lays bare newspaper dark arts at Leveson, The Guardian, 30 November, 16.

Sen, Piyal and Deji, Adekele (2007) 'Sex Sells, But Does it Help? A Survey of Media Coverage in a Medium Secure Unit Treating Sex Offenders’. Mental Health Review Journal 12(3): $15-21$.

Silverman, Jon and Wilson, David (2002) Innocence Betrayed: Paedophilia, the Media and Society. Cambridge: Polity Press.

Smith, Joan (1990) Misogynies. London: Faber and Faber.

Smith, Roger (1981) Trial by Medicine: Insanity and Responsibility in Victorian Trials. Edinburgh: Edinburgh University Press.

Stanyer, James (2007) Modern Political Communication: Mediated Politics in Uncertain Times. Cambridge: Polity Press.

Thornicroft, Graham (2006) Shunned: Discrimination Against People With Mental Illness, Oxford: Oxford University Press.

Turner, Geoff (1996) 'News media chronicle, July 1995 to June 1996'. Australian Studies in Journalism 5: 265-311.

Watson, Tom and Hickman, Martin (2012) Dial M for Murdoch: News Corporation and the Corruption of Britain, London: Allen Lane.

Wessely, Simon (2012) ‘Anders Breivik, the public, and psychiatry’. The Lancet 379: 1563-1564.

Winchester, Simon (1999) The Surgeon of Crowthorne: A Tale of Murder, Madness and the Oxford English Dictionary. London: Penguin Books.

Wring, Dominic (2012) 'It’s just business': the political economy of the hacking scandal'. Media, Culture and Society, Vol. 34(5) 631-636. 
${ }^{i}$ Thanks to Professor David Deacon for hammering home the main line of argument. Thanks also to Professor Yvonne Jewkes, supportive anonymous referees and journal editors. 